Tropical Journal of Pharmaceutical Research April 2020; 19 (4): 707-714

ISSN: $1596-5996$ (print); 1596-9827 (electronic)

(C) Pharmacotherapy Group, Faculty of Pharmacy, University of Benin, Benin City, 300001 Nigeria.

\title{
Cytochrome P450 expression-associated multiple-hit pathogenesis of non-alcoholic fatty liver disease (NAFLD) in HepG2 cells
}

\author{
Nadta Sukkasem ${ }^{1}$, Waranya Chatuphonprasert ${ }^{2}$, Kanokwan Jarukamjorn ${ }^{1 *}$ \\ ${ }^{1}$ Research Group for Pharmaceutical Activities of Natural Products using Pharmaceutical Biotechnology (PANPB), Faculty of \\ Pharmaceutical Sciences, Khon Kaen University, Khon Kaen 40002, ${ }^{2}$ Faculty of Medicine, Mahasarakham University, \\ Mahasarakham 44000, Thailand
}

*For correspondence: Email: kanok_ja@kku.ac.th; Tel/Fax: +66-43-202379

Sent for review: 17 December 2019

Revised accepted: 31 January 2020

\begin{abstract}
Purpose: To establish a free fatty acid (FFA)-induced non-alcoholic fatty liver disease (NAFLD) model in HepG2 cells.

Methods: HepG2 cells were incubated with 0.1 , 1, or $5 \mathrm{mM}$ oleic acid (OA) or palmitic acid (PA) for 24

h. Histological features were examined by oil-red-O staining. Expression levels of metabolic genes (peroxisome proliferator activated receptors $\alpha / y$, sterol regulatory element binding proteins $1 \mathrm{a} / 1 \mathrm{c}$, acetylCoA carboxylase, acyl-CoA oxidase, and fatty acid synthase), antioxidative genes (catalase and superoxide dismutases 1/2), and cytochrome P450 genes (CYP1A2, CYP2C19, CYP2D6, CYP2E1, CYP3A4, and CYP4A11) were determined by reverse transcription-real time polymerase chain reaction (RT-qPCR).

Results: Intracellular lipid storage was observed in cells treated with $1 \mathrm{mM} \mathrm{OA}$ or PA while cell shrinkage was present at $5 \mathrm{mM}$ concentrations of both. Expression of all metabolic genes were elevated by $1 \mathrm{mM} \mathrm{PA}$ and $5 \mathrm{mM} \mathrm{OA}$ and PA. Expression of all antioxidative genes were diminished by $5 \mathrm{mM} O A$ whereas $5 \mathrm{mM} P A$ only reduced superoxide dismutase-2 expression. Expression of CYP1A2, CYP2D6, and CYP3A4 genes were down-regulated by both FFAs, CYP2C19 was induced by PA, while CYP2E1 and CYP4A11 were up-regulated in a concentration-dependent manner.

Conclusion: PA was the more potent steatogenic agent in an OA- or PA- induced NAFLD model in HepG2 cells. Increase in intracellular hepatic lipid and expression of metabolic genes, suppression of antioxidative genes, suppression of CYP1A2, CYP2D6, and CYP3A4, and induction of CYP2E1 and CYP4A11 correlated with the multiple-hit pathogenesis model of NAFLD. These findings suggest that PA-induced NAFLD model in HepG2 cells is a suitable in vitro model for studying novel therapeutic approaches to NAFLD treatment.
\end{abstract}

Keywords: NAFLD, Multiple-hit pathogenesis, Free fatty acid, Oleic acid, Palmitic acid

This is an Open Access article that uses a fund-ing model which does not charge readers or their institutions for access and distributed under the terms of the Creative Commons Attribution License (http://creativecommons.org/licenses/by/4.0) and the Budapest Open Access Initiative (http://www.budapestopenaccessinitiative.org/read), which permit unrestricted use, distribution, and reproduction in any medium, provided the original work is properly credited.

Tropical Journal of Pharmaceutical Research is indexed by Science Citation Index (SciSearch), Scopus, International Pharmaceutical Abstract, Chemical Abstracts, Embase, Index Copernicus, EBSCO, African Index Medicus, JournalSeek, Journal Citation Reports/Science Edition, Directory of Open Access Journals (DOAJ), African Journal Online, Bioline International, Open-J-Gate and Pharmacy Abstracts

\section{INTRODUCTION}

Non-alcoholic fatty liver disease (NAFLD) is a major chronic liver disease affecting around $30 \%$ of Western and Asian populations [1]. To date, fatty liver disease patients have been given lifestyle modification advice comprised of recommendations on diet and encouragement to 
exercise as no effective treatment has been reported. The development of NAFLD is associated with excess fat consumption and metabolic syndromes [1]. Fatty acids are involved in lipogenesis and development of hepatic fat accumulation. Oleic acid (OA) and palmitic acid (PA) are the most common dietary fatty acids. $O A$ is the most abundant fatty acid in triglyceride (TG) stored in human adipose tissue followed by PA [2]. Monounsaturated OA (C18:1 $n-9)$ is found in vegetable oils including olive, sunflower, safflower, and canola and in animal fats from beef, pork, camel, and krill [3]. Saturated PA (C16:0) is found in beef, palm oil, lard, and unsalted butter [4]. Previous studies in primary hepatocytes, immortalized hepatic cell lines, mice, geese, and humans have suggested induction of NAFLD by OA, PA, and their combinations occurs through cytotoxic effects, disruption of the lipid metabolic and oxidantantioxidant systems, and alteration of cytochrome P450 (CYP) profiles [5].

CYP is a superfamily of mono-oxygenase enzymes that are highly abundant in the liver and play a key role in metabolism of drugs, xenobiotics, and toxic chemicals [6]. CYPs have been implicated in the pathogenesis of fatty liver disease by promoting oxidative stress and inflammation, however the metabolic pathways have not been sufficiently described [6].

This study aimed to establish an in vitro NAFLD model in HepG2 cells to investigate the modulation of metabolic systems during steatohepatitis. NAFLD pathogenesis is believed to occur through multiple-hit including insulin resistance, mitochondrial dysfunction, endoplasmic reticulum (ER) stress, oxidantantioxidant imbalance, and inflammation, all of which are targets for NAFLD therapies. Therefore, hepatosteatosis was induced in HepG2 cells with OA and PA to examine the association of CYP450 regulation with multiplehit pathogenesis of NAFLD.

\section{EXPERIMENTAL}

\section{Chemicals}

Dulbecco's modified Eagle medium (DMEM) [+] $1 \mathrm{~g} / \mathrm{L}$ D-glucose [+] L-glutamine [+] $110 \mathrm{mg} / \mathrm{mL}$ sodium pyruvate, and fetal bovine serum (FBS) were purchased from Gibco $^{\circledR}$ (Life Technologies $^{\mathrm{TM}}$, MA, USA). Oleic acid (OA; O1008), palmitic acid (PA; P0500), oil red O were obtained from Sigma-Aldrich (Missouri, USA). All other laboratory chemicals were of the highest purity from commercial suppliers.

\section{Experimental design and treatment}

HepG2 cells (ATCC ${ }^{\circledR}$ HB-8065, Manassas, USA) were cultured in DMEM supplemented with $10 \%$ FBS and 10,000 units/mL penicillin/streptomycin at $37^{\circ} \mathrm{C}$ under $95 \%$ humidity and $5 \% \mathrm{CO}_{2}$. The cells were seeded in a 6-well plate at a density of $5 \times 10^{5}$ cells/well until reaching to $80 \%$ confluence. Stock solutions (1 M) of OA and PA were prepared by dissolving in isopropanol and diluted with medium to $0.1,1$, and $5 \mathrm{mM}$ before incubating with the cells for $24 \mathrm{~h}$. Then the medium and the cells were collected for further analysis.

\section{Examination of intracellular fat by oil red 0 staining}

Oil red $\mathrm{O}$ solution (ORO; $0.18 \%$ ) was freshly prepared in $60 \%$ isopropanol. At $24 \mathrm{~h}$ after the last treatment, the medium was removed, and the monolayer cells were washed with phosphate buffered saline (PBS). The cells were fixed by immersing in $10 \%$ neutral-buffered formalin and washed twice with distilled water, followed by immersing in $60 \%$ isopropanol. Then the fixed cells were stained with ORO. The background was cleaned via immersing in $60 \%$ isopropanol, followed by washing with distilled water. The histological features were evaluated using a Motic AE2000 inverted microscope at 10x magnification (Motic, Kowloon, Hong Kong). The image was recorded and analyzed on screen using a Motic image plus 3.0 software [7].

\section{Determination of mRNA expression by reverse transcription/real-time polymerase chain reactions (RT/qPCR)}

Total RNA was prepared by guanidinethiocyanate-phenol-chloroform method [8] and the concentration was determined by NanoDrop 2000c UV-spectrophotometer (NanoDrop Technologies, Inc., Thermo Fisher Scientific, MA, USA). Total RNA was converted to cDNA using ReverTraAce ${ }^{\circledR}$ (Toyobo Co., Ltd., Osaka, Japan) at $25^{\circ} \mathrm{C}$ for $10 \mathrm{~min}, 42^{\circ} \mathrm{C}$ for $60 \mathrm{~min}$, and $95^{\circ} \mathrm{C}$ for $5 \mathrm{~min}$. Expressions of metabolic genes, i.e. PPAR- $\alpha$, PPAR- $y$, SREBP-1a, SREBP-1c, ACC, COX, and FAS, antioxidative genes, CAT, SOD1, and SOD2, CYPs, i.e. CYP1A2, CYP2C19, CYP2D6, CYP2E1, CYP3A4, and CYP4A11, and $\beta$-actin were subjected to qPCR with the specific primers (Table 1) under conditions recommended by the supplier and calculated as described [8]. The mRNA levels were normalized to that of a reference gene, $\beta$-actin, and expressed as the fold differences to control. 
Table 1: Specific primers for determination of mRNA expressions using Qpcr

\begin{tabular}{|c|c|c|c|}
\hline Gene & & Forward and reverse primers $\left(5^{\prime} \rightarrow 3^{\prime}\right)$ & $\begin{array}{c}\text { Annealing } \\
\text { temperature }\left({ }^{\circ} \mathrm{C}\right) \\
\end{array}$ \\
\hline \multirow{2}{*}{ PPAR- $\alpha$} & Forward & GGT GGA CAC GGA AAG CCC AC & \multirow{2}{*}{60.6} \\
\hline & Reverse & GGA CCA CAG GAT AAG TCA CC & \\
\hline \multirow{2}{*}{ PPAR-Y } & Forward & GGC GAG GGC GAT CTT GAC AGG & \multirow{2}{*}{57.4} \\
\hline & Reverse & TGC GGA TGG CCA CCT CTT TGC & \\
\hline \multirow[t]{2}{*}{ SREBP-1a } & Forward & TCA GCG AGG CGG CTT TGG AGC AG & \multirow[t]{2}{*}{57.4} \\
\hline & Reverse & CAT GTC TTC GAT GTC GGT CAG & \\
\hline \multirow[t]{2}{*}{ SREBP-1C } & Forward & GGA GGG GTA GGG CCA ACG GCC & \multirow[t]{2}{*}{57.4} \\
\hline & Reverse & CAT GTC TTC GAA AGT GCA ATC C & \\
\hline \multirow[t]{2}{*}{$A C C$} & Forward & GAA TGT TTG GGG ATA TTT CAG & \multirow[t]{2}{*}{60.7} \\
\hline & Reverse & TTC TGC TAT CAG TCT GTC CAG & \\
\hline \multirow[t]{2}{*}{$A C O X$} & Forward & GGG CAT GGC TAT TCT CAT TGC & \multirow[t]{2}{*}{60.2} \\
\hline & Reverse & CGA ACA AGG TCA ACA GAA GTT AGG & \\
\hline \multirow[t]{2}{*}{ FAS } & Forward & CGG AAA CTG CAG GAG CTG TC & \multirow[t]{2}{*}{60.0} \\
\hline & Reverse & CAC GGA GTT GAG CCG CAT & \\
\hline \multirow[t]{2}{*}{ CAT } & Forward & AGT GAT CGG GGG ATT CCA GA & \multirow[t]{2}{*}{60.8} \\
\hline & Reverse & GAG GGG TAC TTT CCT GTG GC & \\
\hline \multirow[t]{2}{*}{ SOD1 } & Forward & GGT GTG GCC GAT GTG TCT AT & \multirow[t]{2}{*}{60.6} \\
\hline & Reverse & TGG GCG ATC CCA ATT ACA CC & \\
\hline \multirow[t]{2}{*}{ SOD2 } & Forward & GCA CTA GCA GCA TGT TGA GC & \multirow[t]{2}{*}{60.1} \\
\hline & Reverse & CCG TTA GGG CTG AGG TTT GT & \\
\hline \multirow[t]{2}{*}{ CYP1A2 } & Forward & ACA AGG GAC ACA ACG CTG AA & \multirow[t]{2}{*}{60.0} \\
\hline & Reverse & AGG GCT TGT TAA TGG CAG TG & \\
\hline \multirow[t]{2}{*}{ CYP2C19 } & Forward & ACC CAA AGG ACC TTG ACA CA & \multirow[t]{2}{*}{61.1} \\
\hline & Reverse & AGA TAG TGA AAT TTG GAC CAG AGG A & \\
\hline \multirow[t]{2}{*}{ CYP2D6 } & Forward & AGC TTT CTG GTG ACC CCA TC & \multirow[t]{2}{*}{61.1} \\
\hline & Reverse & GGA CCC GAG TTG GAA CTA CC & \\
\hline \multirow[t]{2}{*}{ CYP2E1 } & Forward & AAT GGA CCT ACC TGG AAG GAC & \multirow[t]{2}{*}{60.0} \\
\hline & Reverse & CCT CTG GAT CCG GCT CTC ATT & \\
\hline \multirow[t]{2}{*}{ CYP3A4 } & Forward & GCC TGG TGC TCC TCT ATC TA & \multirow[t]{2}{*}{54.7} \\
\hline & Reverse & GGC TGT TGA CCA TCA TAA AAG & \\
\hline CYP4A11 & Forward & CCC CTT GTG GCC TTT GG & 60.0 \\
\hline & Reverse & GCG TCA GGG TAG CCT TCC A & \\
\hline$\beta$-actin & Forward & TCC GCA AAG ACC TGT ACA CC & 61.1 \\
\hline & Reverse & GAG TAC TTG CGC TTG GGA GG & \\
\hline
\end{tabular}

\section{RESULTS}

\section{Histomorphology of $\mathrm{OA}$ and PA-induced NAFLD in HepG2 cells}

The histological features of ORO-stained HepG2 cells are shown in Figure 1. The control HepG2 cells demonstrated regular cell characteristics (Figure $1 \mathrm{~A}$ ) while those exposed to $\mathrm{OA}$ and PA free fatty acids (FFA) showed increasing storage of intracellular lipid in a concentration-dependent manner. The lowest concentration $(0.1 \mathrm{mM})$ of OA (Figure $1 \mathrm{C}$ ) or PA (Figure $1 \mathrm{~F}$ ) caused limited accumulation of lipid droplets with otherwise unchanged histomorphology compared to the controls. At the higher concentration (1 $\mathrm{mM}$ ) large numbers of lipid droplets (in red) were observed for both OA (Figure 1 D) and PA (Figure $1 \mathrm{G}$ ). The droplets appeared fused with evidence of cell shrinkage (black arrows) in cells treated with PA ( 1 and $5 \mathrm{mM}$; Figure $1 \mathrm{G}$ and $\mathrm{H}$ ). Large amounts of lipid were present in cells treated with $5 \mathrm{mM}$ OA (Figure $1 \mathrm{E}$ ) and with 1 and $5 \mathrm{mM} \mathrm{PA}$. At these higher concentrations of
PA, the cytoplasmic materials appeared clumped, the cells were condensed and the nuclei had disappeared (Figure $1 \mathrm{G}$ and $\mathrm{H}$ ). These observations revealed that both the FFA type and concentration contributed to the amount of lipid accumulation in HepG2 cells.

Effect of OA- or PA-induced NAFLD on the mRNA expression of metabolic genes in HepG2 cells

Expression of the PPAR- $\alpha$, PPAR- $\gamma$, SREBP-1a, SREBP-1C, ACC, ACOX, and FAS metabolic genes were changed in the FFA-loaded HepG2 cells (Table 2 and Table 3). PPAR- $\alpha$ and ACOX $m R N A s$ were significantly induced by $O A$ and PA at higher concentrations. Expression of PPAR- $\alpha$, PPAR-y, SREBP-1a, SREBP-1c, and ACC mRNAs were elevated by $\mathrm{OA}(5 \mathrm{mM})$ and PA $(0.1-5 \mathrm{mM})$. Expression of FAS mRNA was increased by OA ( $5 \mathrm{mM})$ and PA (1 and $5 \mathrm{mM})$. 

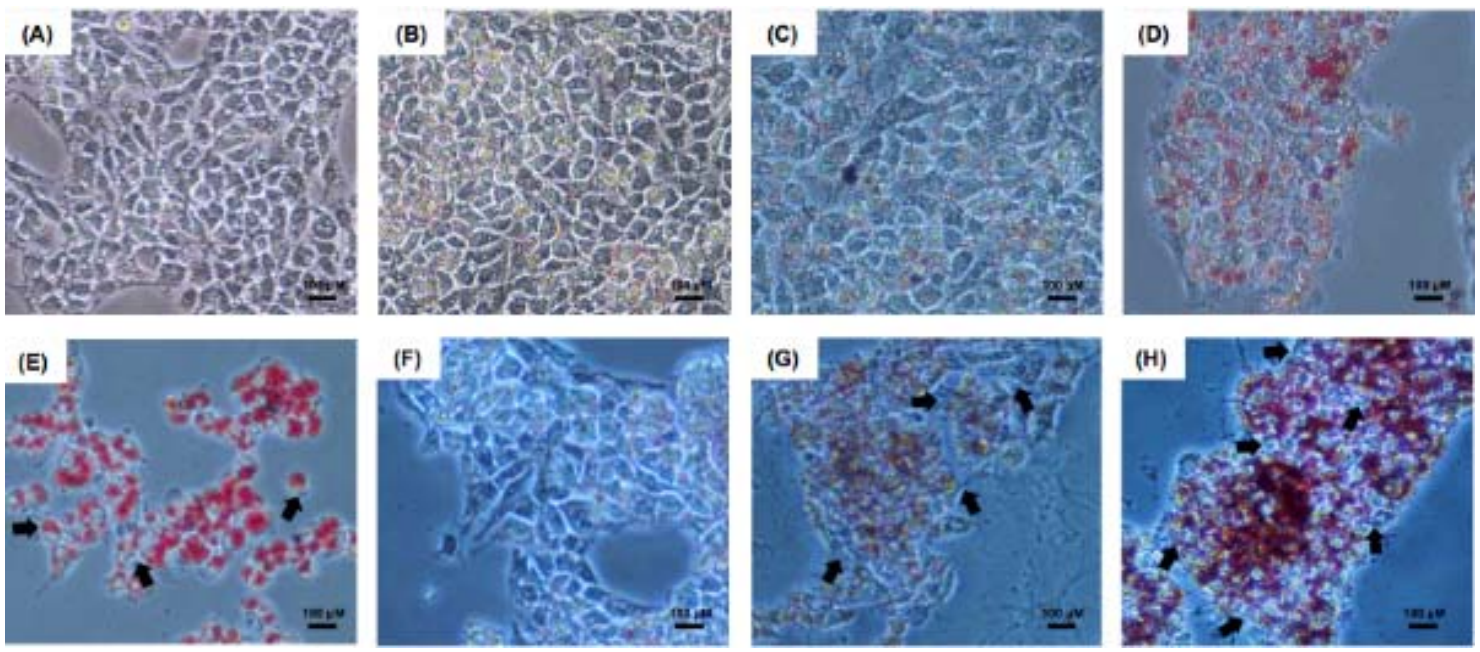

Figure 1: Histomorphology of NAFLD-induced HepG2 cells using oleic acid and palmitic acid. HepG2 cells were treated with (A) non-treatment, $(B)$ control, $0.5 \%$ isopropanol, (C-E) oleic acid in isopropanol at concentrations of $0.1,1$, and $5 \mathrm{mM}$, respectively, and $(\mathrm{F}-\mathrm{H})$ palmitic acid in isopropanol at concentrations of $0.1,1$, and $5 \mathrm{mM}$, respectively

Effect of OA- or PA-induced NAFLD on mRNA expression of antioxidative genes in HepG2 cells

Expression of all antioxidative genes (CAT,
SOD1, and SOD2) in the FFA-loaded HepG2 cells were significantly suppressed at the highest concentration $(5 \mathrm{mM})$ of OA, while PA only downregulated SOD2 (Table 4)

Table 2: Induction of metabolic genes, PPAR- $\alpha$, PPAR- - , SREBP-1a, and SREBP-1c, in OA- and PA-induced NAFLD in HepG2 cells

\begin{tabular}{|c|c|c|c|c|}
\hline \multirow{2}{*}{ Treatment } & \multicolumn{4}{|c|}{ Fold difference (metabolic genes/ $\beta$-actin) } \\
\hline & PPAR- $\alpha$ & PPAR- $Y$ & SREBP-1a & SREBP-1C \\
\hline Control & $1.00 \pm 0.16$ & $1.00 \pm 0.14$ & $1.00 \pm 0.14$ & $1.06 \pm 0.18$ \\
\hline $0.5 \%$ Isopropanol & $0.94 \pm 0.11$ & $0.94 \pm 0.16$ & $0.93 \pm 0.16$ & $0.99 \pm 0.13$ \\
\hline \multicolumn{5}{|l|}{ Oleic acid } \\
\hline $0.1 \mathrm{mM}$ & $0.81 \pm 0.16$ & $1.03 \pm 0.09$ & $1.03 \pm 0.06$ & $0.88 \pm 0.07$ \\
\hline $1 \mathrm{mM}$ & $1.16 \pm 0.18$ * & $1.20 \pm 0.07$ & $1.26 \pm 0.07$ & $1.10 \pm 0.19$ \\
\hline $5 \mathrm{mM}$ & $1.23 \pm 0.14$ * & $1.71 \pm 0.13^{*}$ & $1.70 \pm 0.10$ * & $1.70 \pm 0.31$ * \\
\hline \multicolumn{5}{|l|}{ Palmitic acid } \\
\hline $0.1 \mathrm{mM}$ & $1.03 \pm 0.10$ & $2.01 \pm 0.06$ * & $2.00 \pm 0.06$ * & $1.81 \pm 0.07$ * \\
\hline $1 \mathrm{mM}$ & $1.32 \pm 0.11$ * & $2.57 \pm 0.20^{* *}$ & $2.55 \pm 0.16$ * & $2.73 \pm 0.30$ * \\
\hline $5 \mathrm{mM}$ & $1.57 \pm 0.04$ * & $3.20 \pm 0.06^{* *}$ & $3.15 \pm 0.06^{* *}$ & $4.14 \pm 0.12^{* *}$ \\
\hline
\end{tabular}

${ }^{*} p<0.05,{ }^{* *} p<0.001$ vs. control using one-way ANOVA with Tukey post hoc test

Table 3: Induction of metabolic genes, ACC, ACOX, and FAS, in OA- and PA-induced NAFLD in HepG2 cells

\begin{tabular}{lccc}
\hline \hline \multirow{2}{*}{ Treatment } & \multicolumn{2}{c}{ Fold difference (metabolic gene/ $\beta$-actin) } \\
\cline { 2 - 4 } & ACC & ACOX & FAS \\
\hline Control & $1.09 \pm 0.18$ & $1.02 \pm 0.20$ & $1.01 \pm 0.16$ \\
\hline $\mathbf{0 . 5} \%$ Isopropanol & $0.94 \pm 0.12$ & $1.07 \pm 0.15$ & $0.99 \pm 0.17$ \\
\hline Oleic acid & & & \\
$0.1 \mathrm{mM}$ & $1.00 \pm 0.04$ & $0.83 \pm 0.14$ & $0.89 \pm 0.17$ \\
$1 \mathrm{mM}$ & $1.21 \pm 0.16$ & $1.45 \pm 0.28^{*}$ & $1.10 \pm 0.18$ \\
$5 \mathrm{mM}$ & $1.44 \pm 0.18^{*}$ & $1.89 \pm 0.23^{*}$ & $1.37 \pm 0.20^{*}$ \\
Palmitic acid & & & \\
$0.1 \mathrm{mM}$ & $1.35 \pm 0.15^{*}$ & $1.33 \pm 0.14^{*}$ & $0.91 \pm 0.01$ \\
$1 \mathrm{mM}$ & $1.62 \pm 0.39^{*}$ & $1.43 \pm 0.30^{*}$ & $1.59 \pm 0.07^{* *}$ \\
$5 \mathrm{mM}$ & $2.22 \pm 0.11^{* *}$ & $2.26 \pm 0.28^{* *}$ & $2.39 \pm 0.06^{* *}$ \\
\hline \hline${ }^{*} \mathrm{p}<0.05,{ }^{* *} p<0.001$ vs control using one-way ANOVA with Tukey post hoc test
\end{tabular}


Table 4: Modification of antioxidative genes, CAT, SOD1, and SOD2, in OA- and PA-induced NAFLD in HepG2 cells

\begin{tabular}{lccc}
\hline \hline \multirow{2}{*}{ Treatment } & \multicolumn{2}{c}{ Fold difference (antioxidative genes/B-actin) } \\
\cline { 2 - 4 } & \multicolumn{1}{c}{ CAT } & SOD1 & SOD2 \\
\hline Control & $1.10 \pm 0.10$ & $1.00 \pm 0.08$ & $1.05 \pm 0.21$ \\
\hline O.5\% Isopropanol & $1.19 \pm 0.15$ & $0.98 \pm 0.17$ & $1.04 \pm 0.04$ \\
\hline Oleic acid & & & \\
$0.1 \mathrm{mM}$ & $0.84 \pm 0.03$ & $1.11 \pm 0.16$ & $1.19 \pm 0.06$ \\
$1 \mathrm{mM}$ & $0.67 \pm 0.10$ & $0.85 \pm 0.16$ & $0.75 \pm 0.14$ \\
$5 \mathrm{mM}$ & $0.19 \pm 0.03^{* *}$ & $0.44 \pm 0.05^{*}$ & $0.45 \pm 0.02^{*}$ \\
Palmitic acid & & & \\
$0.1 \mathrm{mM}$ & $1.32 \pm 0.13^{* *}$ & $1.09 \pm 0.17$ & $0.47 \pm 0.09^{*}$ \\
$1 \mathrm{mM}$ & $0.95 \pm 0.07$ & $0.90 \pm 0.02$ & $0.44 \pm 0.04^{*}$ \\
$5 \mathrm{mM}$ & $0.69 \pm 0.23$ & $0.84 \pm 0.21$ & $0.42 \pm 0.02^{*}$ \\
\hline \hline
\end{tabular}

${ }^{*} p<0.05,{ }^{* \star} p<0.001$ vs. control using one-way ANOVA with Tukey post hoc test

Table 5: Modification of CYPs, CYP1A2, CYP2C19, CYP2D6, and CYP3A4, in OA- and PA-induced NAFLD in HepG2 cells

\begin{tabular}{|c|c|c|c|c|}
\hline \multirow{2}{*}{ Treatment } & \multicolumn{4}{|c|}{ Fold difference (CYPs/ $\beta$-actin) } \\
\hline & CYP1A2 & CYP2C19 & CYP2D6 & CYP3A4 \\
\hline Control & $1.10 \pm 0.16$ & $1.00 \pm 0.11$ & $1.05 \pm 0.05$ & $1.05 \pm 0.16$ \\
\hline $0.5 \%$ Isopropanol & $0.97 \pm 0.18$ & $1.02 \pm 0.17$ & $1.08 \pm 0.04$ & $1.00 \pm 0.12$ \\
\hline \multicolumn{5}{|l|}{ Oleic acid } \\
\hline $0.1 \mathrm{mM}$ & $0.96 \pm 0.19$ & $1.06 \pm 0.01$ & $1.15 \pm 0.10$ & $0.62 \pm 0.08$ ** \\
\hline $1 \mathrm{mM}$ & $0.75 \pm 0.05$ * & $0.69 \pm 0.10$ ** & $1.05 \pm 0.00$ & $0.59 \pm 0.17^{* *}$ \\
\hline $5 \mathrm{mM}$ & $0.62 \pm 0.00$ * & $0.31 \pm 0.02$ ** & $0.96 \pm 0.12$ & $0.41 \pm 0.02$ ** \\
\hline \multicolumn{5}{|l|}{ Palmitic acid } \\
\hline $0.1 \mathrm{mM}$ & $0.77 \pm 0.04$ * & $1.79 \pm 0.03^{* *}$ & $1.30 \pm 0.02$ * & $0.39 \pm 0.04 * *$ \\
\hline $1 \mathrm{mM}$ & $0.77 \pm 0.04$ * & $1.64 \pm 0.02$ ** & $0.65 \pm 0.05$ * & $0.14 \pm 0.01$ ** \\
\hline $5 \mathrm{mM}$ & $0.52 \pm 0.01 * *$ & $1.03 \pm 0.07$ & $0.59 \pm 0.07$ * & $0.07 \pm 0.07$ ** \\
\hline
\end{tabular}

\section{Effect of OA- or PA-induced NAFLD on mRNA expression of CYPs in HepG2 cells}

Expression of CYP1A2 mRNA was significantly suppressed by all OA or PA treatments, except $\mathrm{OA}$ at the concentration of $0.1 \mathrm{mM}$ (Table 5). Expression of CYP2C19 mRNA was suppressed by OA ( 1 and $5 \mathrm{mM})$ but induced by PA ( 0.1 and $1 \mathrm{mM}$ ) (Table 5). OA did not change expression of CYP2D6, while PA induced CYP2D6 at the lowest concentration but suppressed it at the two higher concentrations ( 1 and $5 \mathrm{mM}$, Figure $5 \mathrm{~A}$ ). The expression of CYP3A4 was suppressed by $\mathrm{OA}$ and $\mathrm{PA}$ in a concentration-dependent manner (Table 5). The expression of CYP2E1 and CYP4A11 mRNA were increased by OA ( 5 $\mathrm{mM}$ ) and all PA treatments (Table 6).

\section{DISCUSSION}

This study optimized an in vitro model of NAFLD in HepG2 cells and explored the effect of OAand PA-induced NAFLD on intracellular lipid levels and mRNA expression of metabolic, antioxidative, and CYP genes. This model was developed using HepG2 cells at the density of 5 $\times 10^{5}$ cells/well with $\mathrm{OA}$ and PA at various concentrations that correlated to human diets
Table 6 Modification of CYPs, CYP2E1 and CYP4A11, in OA- and PA-induced NAFLD in HepG2 cells

\begin{tabular}{lcc}
\hline \hline \multirow{2}{*}{ Treatment } & \multicolumn{2}{c}{ Fold-difference (CYPs/ $\beta$-actin) } \\
\cline { 2 - 3 } & CYP2E1 & CYP4A11 \\
\hline Control & $1.00 \pm 0.13$ & $1.01 \pm 0.20$ \\
\hline O.5\% Isopropanol & $1.03 \pm 0.23$ & $1.00 \pm 0.05$ \\
\hline Oleic acid & & \\
$0.1 \mathrm{mM}$ & $1.01 \pm 0.14$ & $0.99 \pm 0.06$ \\
$1 \mathrm{mM}$ & $1.23 \pm 0.16$ & $1.29 \pm 0.06$ \\
$5 \mathrm{mM}$ & $2.03 \pm 0.17^{*}$ & $1.47 \pm 0.28^{*}$ \\
Palmitic acid & & \\
$0.1 \mathrm{mM}$ & $2.46 \pm 0.03^{*}$ & $1.70 \pm 0.25^{*}$ \\
$1 \mathrm{mM}$ & $3.15 \pm 0.03^{*}$ & $3.96 \pm 0.20^{*}$ \\
$5 \mathrm{mM}$ & $4.98 \pm 0.05^{* *}$ & $4.97 \pm 0.10^{* *}$ \\
\hline \hline${ }^{*} p<0.05,{ }^{* *} p<0.001$ vs. control using one-way \\
ANOVA with Tukey post hoc test
\end{tabular}

ranged from 0.1 to $1 \mathrm{mM}$ [9]. The advantages of HepG2 cells are that this cell type carries an adiponutrin variant responsive to hepatic fat accumulation, they are easy to handle and culture with high reproducibility, low cost, and relatively stable in gene expression profiles. The HepG2 adiponutrin variant $\| \mathrm{e}^{148} \mathrm{Met}$ is emphatically associated with liver fat content, especially TG, the main fat accumulated in the liver and the major cause of fatty liver disease. This HepG2 adiponutrin variant has been shown 
to increase intracellular TG content and TG concentrations in media [10]. In the current study, accumulation of intracellular lipid was demonstrated by changes to histomorphological features. HepG2 cells treated with PA at $1 \mathrm{mM}$ and $\mathrm{OA}$ and $\mathrm{PA}$ at $5 \mathrm{mM}$ demonstrated fat overloading with karyopyknotic cell shrinkage and the presence of apoptotic bodies indicating up-regulation of metabolic genes. The findings that PA provided more steatogenic effects and apoptotic induction was in agreement with previous studies [11].

One of the markers of multiple-hit pathogenesis of NAFLD comprises induction of FFA synthetic pathways through PPAR- $\alpha$, PPAR-y, SREBP-1a, SREBP-1C, ACC, ACOX, and FAS, which not only directly affect lipogenesis but also influence insulin resistance $[12,13]$. In our hands, OA or PA dramatically increased expression of those metabolic genes, and PA at $1 \mathrm{mM}$ was the optimal concentration for NAFLD induction in the HepG2 model.

Regarding NAFLD, fat accumulates in the liver as TG by esterification of FFAs and glycerol. Once FFAs enter hepatocytes, they form fatty acyl-CoAs through acyl-CoA synthase. Fatty acyl-CoAs could then pass into either the $\beta$ oxidation pathway or esterification, which results in hepatic fat accumulation [14]. The highest dose of OA and all doses of PA induced SREBP. $1 \mathrm{C}$, resulting in up-regulation of hepatic de novo lipogenesis and hepatic fat accumulation. Moreover, upregulation of ACC, ACOX, and FAS prompt insulin resistance.

Insulin resistance inhibits $\beta$-oxidation of FFAs, promoting fat accumulation in the liver [13]. This supports PA activating insulin resistance more than $O A$. At the same concentration, OA stimulated only ACOX expression while PA triggered increased ACC, ACOX, and FAS expression. High dose of FFAs in hepatocytes induces FAS to activate serine-kinase to induce a defect in insulin signaling pathways, resulting in insulin resistance. Insulin suppresses adipose tissue lipolysis; hence, increased insulin resistance diminishes this repression, leading to increased supply of FFAs to the liver [15]. Although $\mathrm{OA}$ at $5 \mathrm{mM}$ induced FAS, PA demonstrated more specificity increasing expression at the lowest concentration.

The observed reductions of CAT and SOD in our model indicated oxidative stress. SOD consists of 3 subtypes [16]. SOD1 is located in the cytoplasm while SOD2 is in the mitochondria and SOD2 polymorphisms are significantly correlated with liver injury. SOD3 is found extracellularly.
Alteration of mitochondrial or peroxisomal function impairs a cells ability to handle an increase in lipid flux, resulting in destruction of fat homeostasis and generation of toxic metabolites via overproduction of lipid and reactive oxygen species (ROS), finally causing hepatocyte necroinflammation and exacerbation of mitochondrial damage [14]. The highest concentration of $\mathrm{OA}$ led to down-regulation of CAT, SOD1, and SOD2, while PA suppressed only SOD2, but it did so from the lowest concentration. Suppression of SOD2 enhances oxidative stress via mitochondrial dysfunction. Since this occurred even at the lowest concentration of PA, this suggests PA was a greater pro-oxidant than OA.

The modulation of CYP expression observed in our model correlated to the degree of steatosis. While the highest concentration of OA upregulated CYP2E1 and CYP4A11, the lowest concentration of PA was able to significantly increase expression of CYP2E1 and CYP4A11. These results correlate with previous studies that showed $\mathrm{OA}$ and $\mathrm{PA}$ increase the level of CYP2E1 and CYP4A11 in rodents, human hepatocytes, and differentiated human cells $[17,18]$. Induction of CYP2E1 and CYP4A11 impairs both the ER and mitochondria. Mitochondrial impairment leads to electron leakage during the mitochondrial respiratory chain process and metabolism phase, resulting in lipid peroxidation, ROS overproduction, and oxidative stress. ER impairment activates the unfolded protein response (UPR) and activates c-Jun N-terminal kinase (JNK), which trigger inflammation, apoptosis, and insulin resistance $[13,19]$.

Furthermore, increased CYP2E1 and CYP4A11 expression and concomitant exposure to their substrate drugs can lead to severe cellular injury due to the over-production of toxic metabolites, such as acetone from CYP2E1 and ketone bodies from CYP4A11 [20,21]. These findings support that CYP2E1 induces fatty liver disease whether it is induced by alcohol, or not $[22,23]$. Previous investigations have demonstrated a relationship between NAFLD progression and decreased activity of CYP1A2, CYP2D6, and CYP3A4 [18,24]. In our model, PA reduced expression of CYP1A2, CYP2D6, and CYP3A4, while OA down-regulated CYP1A2 and CYP3A4. The expression of CYP2C19 has been reported either as induction or inhibition in humans $[18,25]$. Concentrations of 1 and $5 \mathrm{mM}$ OA decreased CYP2C19 expression while 0.1 and 1 mM PA induced CYP2C19. These findings 
suggest that modulation of CYP2C19 expression was dependent on the structure of the FFA.

The present model revealed the relevance of the FFA-concentration to the degree of steatosis. The activation of PPAR- $\alpha$, PPAR- $\gamma$, SREBP-1a, SREBP-1c by fat accumulation in the liver causes lipotoxicity, mitochondrial dysfunction, and ER stress. Furthermore, the induction of ACC, ACOX, and FAS, which are down-stream of the carbohydrate-responsive element-binding protein (ChREBP) and SREBP, indicates the development of insulin resistance while the down-regulation of CAT and SOD2 mRNA expression causes oxidative stress. Taken together, the increases in CYP2E1 and CYP4A11 expression, decreases in CYP1A2, CYP2D6, and CYP3A4 expression and changes in CYP2C19 expression affect the progression of NAFLD via ER and mitochondrial injury and potentially through an increase in toxic products from clinical drug metabolism and the associated imbalance in the expression of metabolic and anti-oxidative genes potentially authorizes gene mutations. This correlation of multiple changes to CYP450 regulatory profiles and metabolic and anti-oxidative gene expression support the multiple-hit pathogenesis model of NAFLD progression.

\section{CONCLUSION}

This study has established a novel in vitro NAFLD model in HepG2 cell derived multiple-hit pathogenesis associated with regulation of CYP450s. PPAR- $\alpha$, PPAR- $\gamma$, SREBP-1a, SREBP-1C, ACC, ACOX, and FAS were induced while CAT and SOD2 were suppressed. CYP2E1 and CYP4A11 were elevated while CYP1A2, CYP2C19, CYP2D6 and CYP3A4 were attenuated. PA was a more potent steatogenic agent with less apoptotic effects than OA. PA at a concentration of $1 \mathrm{mM}$ was optimal for induction of NAFLD in HepG2 cell.

\section{DECLARATIONS}

\section{Acknowledgement}

NS sincerely thanks Faculty of Pharmaceutical Sciences, Khon Kaen University, Thailand for scholarship and facilities and the Research Group for Pharmaceutical Activities of Natural Products using Pharmaceutical Biotechnology (PANPB), Khon Kaen University for the research grant. The authors thank Dr. Glenn Borlace, Faculty of Pharmaceutical Sciences, Khon Kaen University for English language assistance.

\section{Conflict of interest}

No conflict of interest is associated with this study.

\section{Contribution of authors}

The authors declare that this work was done by the authors named in this article and that all liabilities pertaining to claims relating to the content of this article will be borne by them. NS carried out the experiments and statistical analysis, and drafted the manuscript. WC supervised the experimental work, verified the data, and proved the draft of manuscript. KJ designed the conceptual framework and revised the manuscript. The manuscript was comprehensively read and approved for publication by all authors.

\section{Open Access}

This is an Open Access article that uses a funding model which does not charge readers or their institutions for access and distributed under the terms of the Creative Commons Attribution License (http://creativecommons.org/licenses/by/ 4.0) and the Budapest Open Access Initiative (http://www.budapestopenaccessinitiative.org/rea d), which permit unrestricted use, distribution, and reproduction in any medium, provided the original work is properly credited.

\section{REFERENCES}

1. Bellentani S, Scaglioni F, Marino M, Bedogni G. Epidemiology of non-alcoholic fatty liver disease. Dig Dis 2010; 28(1): 155-161.

2. Oliveira $A F$, Cunha $D A$, Ladriere L, Igoillo-Esteve $M$, Bugliani $M$, Marchetti $P$, Cnop $M$. In vitro use of free fatty acids bound to albumin: a comparison of protocols. Biotechiques 2015; 58(5): 228-233.

3. Choi YS, Lee JK, Jung JT, Jung YC, Jung JH, Jung MO, Choi YI, Jin SK, Choi JS. Comparison of meat quality and fatty acid composition of Longissimus muscles from purebred pigs and three-way crossbred LYD pigs. Korean J food Sci Anim Resour 2016; 36(5): 689-696.

4. Fattore E, Fanelli R. Palm oil and palmitic acid: a review on cardiovascular effects and carcinogenicity. Int $J$ Food Sci Nutr 2013; 64(5): 648-659.

5. Anstee QM, Goldin RD. Mouse models in non-alcoholic fatty liver disease and steatohepatitis research. Int J Exp Pathol 2006; 87(1): 1-16.

6. Salder NC, Webb-Robertson BM, Clauss TR, Pounds JG, Corley R, Wright AT. High-fat diets alter the modulatory effects of xenobiotics on cytochrome P450 activities. Chem Res Toxicol 2018; 31(5): 308-318.

Trop J Pharm Res, April 2020; 19(4): 713 
7. Jang E, Shin MH, Kim KS, Kim Y, Na YC, Woo HJ, Kim $Y$, Lee JH, Jang HJ. Anti-lipoapoptotic effect of Artemisia capillaris extract on free fatty acids-induced HepG2 cells. BMC Complement Altern Med 2014; 14: 253.

8. Chatuphonprasert W, Jarukamjorn K, Putalun W. Regulation of cancer-related genes - Cyp1a1, Cyp1b1, Cyp19, Nqo1 and Comt - expression in naphthoflavone treated mice by miroestrol. J Pharm Pharmacol 2016; 68(4): 475-484.

9. Kanuri G, Landmann M, Priebs J, Spruss A, Löscher M, Ziegenhardt D, Röhl C, Degan C, Berghiem I. Moderate alcohol consumption diminishes the development of non-alcoholic fatty liver disease (NAFLD) in ob/ob mice. Eur J Nutr 2016; 55(3): 1153-1164.

10. Guo L, Dial S, Shi L, Branham W, Liu J, Fang JL, Green $B$, Deng H, Kaput J, Ning B. Similarities and differences in the expression of drug-metabolizing enzymes between human hepatic cell lines and primary human hepatocytes. Drug Metab Dispos 2011; 39(3): 528-538.

11. Ricchi M, Odoardi MR, Carulli L, Anzivino C, Ballestri S, Pinetti A, Fantoni LI, Marra F, Bertolotti M, Banni S, et al. Differential effect of oleic and palmitic acid on lipid accumulation and apoptosis in cultured hepatocytes. $J$ Gastroenterol Hepatol 2009; 24(5): 830-840.

12. Buzzetti E, Pinzani M, Tsochatzis EA. The multiple-hit pathogenesis of non-alcoholic fatty liver disease (NAFLD). Metabolism 2016; 65(8): 1038-1048.

13. Lewis GF, Carpentier A, Adeli K, Giacca A. Disordered fat storage and mobilization in the pathogenesis of insulin resistance and type 2 diabetes. Endocr Rev 2002; 23(2): 201-229.

14. Basaranoglu M, Basaranoglu G, Bugianesi E. Carbohydrate intake and nonalcoholic fatty liver disease: fructose as a weapon of mass destruction. Hepatobiliary Surg Nutr 2015; 4(2): 109-116.

15. Sears B, Perry $M$. The role of fatty acids in insulin resistance. Lipids Health Dis 2015; 14: 121.

16. Kim SH, Kim SH, Lee JH, Lee BH, Yoon HJ, Shin $D H$, Park SS, Jang SB, Park JS, Jee YK. Superoxide dismutase gene (SOD1, SOD2, and SOD3) polymorphisms and antituberculosis drug-induced hepatitis. Allergy Asthma Immunol Res 2015; 7(1): 8891.

17. Sung M, Kim I, Park M, Whang Y, Lee M. Differential effects of dietary fatty acids on the regulation of CYP2E1 and protein kinase $C$ in human hepatoma HepG2 cells. J Med Food 2004; 7(2): 197-203.

18. Yao HT, Chang YW, Lan SJ, Chen CT, Hsu, JTA, Yeh TK. The inhibitory effect of polyunsaturated fatty acids on human CYP enzymes. Life Sci 2006; 79(26): 24322440.

19. Aubert J, Begriche K, Knockaert L, Robin MA, Fromenty $B$. Increased expression of cytochrome P450 2E1 in nonalcoholic fatty liver disease: mechanisms and pathophysiological role. Clin Res Hepatol Gastroenterol 2011; 35(10): 630-637.

20. Izuchi R, Ishijima T, Okada S, Abe K, Nakai Y. Hepatic fatty acid biosynthesis in KK-Ay mice is modulated by administration of persimmon peel extract: a DNA microarray study. Food Sci Nutr 2018; 6(6): 1657-1663.

21. Forkert PG, Redza ZM, Mangos S, Park SS, Tam SP. Induction and regulation of CYP2E1 in murine liver after acute and chronic acetone administration. Drug Metab Dispos 1994; 22(2): 248-253.

22. Uzbay IT, Usanmaz SE, Akarsu ES. Effects of chronic ethanol administration on serotonin metabolism in the various regions of the rat brain. Neurochem Res 2000; 25(2): 257-262.

23. Mahli A, Thasler WE, Patsenker E, Müller S, Stickel F, Müller M, Seitz HK, Cederbaum Al, Hellerbrand C. Identification of cytochrome CYP2E1 as critical mediator of synergistic effects of alcohol and cellular lipid accumulation in hepatocytes in vitro. Oncotarget 2015; 6(39): 41464-41478.

24. Huang Z, Wang M, Liu L, Peng J, Guo C, Chen X, Huang $L$, Tan J, Yang G. Transcriptional repression of CYP3A4 by increased miR-200a-3p and miR-150-5p promotes steatosis in vitro. Front Genet 2019; 10: 484.

25. Zanger UM, Schwab M. Cytochrome P450 enzymes in drug metabolism: regulation of gene expression, enzyme activities, and impact of genetic variation. Pharmacol Ther 2013; 138(1): 103-141. 